\title{
Socioeconomic Differences in Retirement Adjustment among the Elderly Residing in Retirement Homes
}

\author{
DOI: $10.5613 /$ rzs.49.1.4 \\ UDK: 159.922 .63 \\ 364.62-053.9 \\ 364.62-057.75 \\ Prethodno priopćenje \\ Primljeno: 20. 10. 2018.
}

\author{
Želimir BERTIĆ (1) \\ Alma Mater Europaea, Maribor, Slovenia \\ bertic.z@gmail.com \\ Mirjana TELEBUH \\ University of Applied Health Studies, Zagreb, Croatia \\ mirjana.telebuh@zvu.hr \\ Mladen HAVELKA \\ Alma Mater Europaea, Maribor, Slovenia \\ mladen.havelka@gmail.com
}

\section{ABSTRACT}

The ageing of the population in Croatia and an increase in the number of elderly persons who retain their retirement status for a longer period call for more research on retirement adaptation. This study was focussed on providing a clearer insight into the relationship between socioeconomic characteristics and retirement adjustment, as well as the identification of factors that could increase a low level of retirement adjustment in older people. The research was conducted as a survey in spring 2018 in retirement homes in the Croatian town of Bjelovar and the city of Zagreb. It included 211 older people of both genders aged 65 and above. Retirement Adjustment Factor Questionnaire was used to assess Atchley's Model of Retirement Adjustment. The results confirmed the conceptual hypotheses from earlier studies. The socioeconomic characteristics of the participants such as level of education, type of retirement, monthly income level, and type of occupation were associated with the success of retirement adjustment in the Pre-Retirement, Honeymoon, Routine, and Termination phases from Atchley's Model of Retirement Adjustment, while the Honeymoon Phase was related only to retirement length. Aside from promoting academic and public discussions on the topic, the study findings have potential implications for creating social programmes to improve the quality of life of the elderly and provide a better understanding of how the older population living in retirement homes experience retirement.

Key words: retirement adjustment, Atchley's Model of Retirement Adjustment, elderly, retirement homes, socioeconomic differences 


\section{INTRODUCTION}

The population aged 60 and over makes up about $20 \%$ of the population in Europe and Croatia, recording a raping growth (Croatian Bureau of Statistics, 2013: 17; Eurostat, 2016). Moreover, the populations of the European Union Member States have entered the phase of age demographics in which the number of the elderly population is continuously increasing. The number of people over the age of 80 is expected to increase by about $57 \%$ in the $2010-2030$ period (Ehler, Naegele and Reichert, 2011: 5; Akrap et al., 2013).

How important the problems concerning the growth of the elderly population will become depends on the readiness of an entire society for a change in the demographic structure and its consequences. In order to gain a better insight into the extent and characteristics of numerous social issues caused by population ageing, a number of theoretical, developmental and applied scientific studies have been conducted since the 1960s. These efforts have resulted in many global programmes aimed at improving the quality of life and health of the elderly, as well as better family support and social inclusion.

\subsection{Retirement and ageing}

Retirement is usually experienced as an event or a process which requires planning and adjustment, although it can also be interpreted as a transitional phase in life lasting several years (Pinquart and Schindler, 2007; Denton and Spencer, 2009; Ovesnik et al., 2012). The significance of retirement becomes more complex when both subjective and objective measures are taken into account since they determine whether an individual will take an early or regular retirement, or whether it will be voluntary or involuntary (Penezić, Lacković-Grgin and Lukačić, 2014: 65). Researchers have shown interest in this area only recently (Shultz and Wang, 2011: 170). In the period of early industrialisation, only the rich could afford retirement. Ordinary workers were dismissed at a certain age and were left to spend the rest of their lives as best they could, although most of them did not live long enough to retire (Crandall, 1991). As retirement became a general rule (governed by laws and regulations), public policy was directed towards the issues of retirees' rights and prescribed the retirement age (Penezić, Lacković-Grgin and Lukačić, 2014: 65). Solutions chosen by various countries can cause retirement adjustment problems, particularly if the economy is poor, retirement funds impoverished and if regulations and restrictive measures violate pensioners' rights (Warner and Willis, 2001: 229; Penezić Lacković-Grgin and Lukačić, 2014: 65). 
This paper discusses the theoretical approaches, results of our empirical research and social factors of retirement. We expect this study to provide a clearer insight into the relations between and differences in socioeconomic characteristics and retirement adjustment in the elderly who live in retirement homes and, possibly, timely identification of factors which could reduce or prevent poor retirement adjustment.

\subsection{Social theories of ageing and retirement}

Various ageing and retirement theories have been developed based on different perspectives. A number of dominant theories were developed in the 1960s and 1970s. Although they are still generating interest and inspiring reflections (Touhy and Jett, 2014: 74), these theories should be regarded in the context of the period in which they originated.

The Crisis Theory emphasises that retirement generally has a negative and degrading effect on the individual because paid work is a person's main activity in life (Palmore, Fillenbaum and George, 1984). According to this theory, losing this role to retirement leads to lower self-esteem and loss of status, which implies social withdrawal that can lead to different pathologies and low life satisfaction (Brajković, 2011). Blieszner (2000) identified significant inter-individual differences in assessing the effect retirement has on individuals. People who have recently retired perceive retirement as a critical event more often than those who have been retired for a longer period of time, which indicates that people overcome the initial shock caused by retirement as they start to adapt to the new role.

According to the Continuity Theory, some people try to keep the same orientation in life as they grow old and want to keep the same patterns in spite of the obvious changes (Atchley and Barusch, 2004: 12). The Continuity Theory is one of the most frequently used theories in contemporary retirement research, particularly when retirement is considered as an adjustment process (Wang and Shultz, 2010: 177). Penezić, Lacković-Grgin and Lukačić (2014: 65) argue that Atchley (1976, 2000) used the Continuity Theory to develop a model which regards the retirement process as a series of adjustments divided into seven phases:

1. The Phase When Retirement is Still Far Away occurs mostly when people are middle-aged and still work. They generally do not think about retirement, and if they do, it is only sporadically and set into a distant future;

2. The Pre-Retirement Phase occurs when a person is aware that retirement is approaching and thinks intensively about the activities planned for that period in life and those to be undertaken before retirement to make the adjustment successful; 
3. The Honeymoon Phase follows retirement and is a time of euphoria during which people try to engage in all the activities they previously could not. This phase is partially based on a fantasy about retirement and what it should be like. The Honeymoon Phase requires a positive orientation. However, and more importantly, it requires financial assets, which is available only to some retirees;

4. The Disenchantment Phase takes place when retirees realise they cannot adapt to retirement, when they become aware that they have not carried out the activities they planned and imagined, or when they are dissatisfied with them. Retirees do not feel that they contribute anything compared to the time when they worked, they feel let down and depressed. Disappointment can also be caused by a tragic or disruptive event, such as the death of a spouse or sudden illness;

5. The Reorientation Phase takes place after the Disenchantment Phase or sometimes immediately after being retired. This stage starts with interventions and people use their life experiences to develop a realistic view of retirement in accordance with the psychological and social resources they possess;

6. The Retirement Routine Phase occurs when people create a set of criteria as guidelines in their everyday life. Retirees with a satisfactory retirement routine have accepted their role as pensioners, they know what is expected of them, and are at the same time aware of their abilities and limitations;

7. In the Termination of Retirement Phase, people are no longer oriented towards their role as pensioners. They do not think about themselves as retirees because they are preoccupied with other issues, most often with their own or their spouse's illness, frailty or loneliness. When people become too weak to participate in daily activities, their role as pensioners is not a priority anymore and is overshadowed by the role of a frail person, which becomes the most important factor in organising their everyday life.

The Atchley Model $(1976,2000)$ was used in this study both to assess retirement adjustment in older people and as a conceptual model. According to a study carried out on a sample of Croatian pensioners (Penezić, Lacković-Grgin and Bačinić, 2006: 70), out of the six aforementioned adjustment phases (phases 2 through 7), only one has not been identified, the Reorientation Phase. However, an additional factor centred around improving their financial situation (mostly by moonlighting) 
has been identified - the Work Reactivation Factor. While higher results in the Pre-Retirement, Honeymoon and Routine Phase are associated with better adaptation to retirement, and higher results in Disenchantment and the Termination Phase with poorer adjustment (Atchley and Barusch, 2004: 258-261), it is not conceptually clear how the Reactivation Phase identified among Croatian pensioners affects the success of retirement adjustment.

\subsection{Socioeconomic retirement adjustment factors}

Although in most countries, including Croatia, the age of retirement is 65 , a number of workers retire earlier, either voluntarily or due to downsizing or a higher level of flexibility of the retirement system (Pinquart and Schindler, 2007: 443; Croatian Pension Insurance Institute, 2018). About 50\% of early retirements in many western countries can be classified as forced (Van Solinge and Henkens, 2008: 423) and can be associated with lower life satisfaction caused by financial pressure (Heybroek, 2011: 9). People who retire at an older age often adjust to retirement better (Heybroek, Haynes and Baxter, 2015: 175; Latif, 2011: 378), although retiring after the expected age need not always be positive or beneficial (Calvo, Sarkisian and Tamborini, 2013: 81). The social norms which determine the expected retirement age can bear a major impact on retirement adjustment (Van Solinge and Henkens, 2007: 301). Therefore, it seems that the way a person retires has an important role in retirement adjustment. If people decide to retire voluntarily, for example, because they plan to spend their free time with family and friends, there is a positive correlation between this decision and their well-being (De Vaus et al., 2007: 676; Hershey and Henkens, 2014: 233). However, if they are forced into early retirement either for health or work-related reasons, it will have a negative effect on their well-being (Calvo, Haverstick and Sass, 2009: 130; Hershey and Henkens, 2014: 233; Dingemans and Henkens, 2015: 22; Rhee, Mor Barak and Gallo 2016: 50). People who retire early and unexpectedly are more prone to depression, anxiety and stress (Van Solinge and Henkens, 2008: 430; Hershey and Henkens, 2014: 233).

The level of education can also influence short-term and long-term retirement adjustment, as indicated by the large-scale research conducted by Clark and Fawaz (2009) and Wetzel, Huxhold and Tesch-Römer (2016). It was established that participants with a higher education level had a more positive attitude to retirement than those with a lower level of education, and that more educated people were also better informed about retirement adjustment and pensioners' rights (Clark and Fawaz, 2009). A higher level of education grants better social skills and retirement can become an opportunity to follow popular and enjoyable activities (Heybroek, 2011: 12). 
Numerous studies indicated that the suitability of jobs also has an important impact on the retirement process. Elovainio et al. (2005) established that participants who perceived their job as stressful and burdensome planned to retire early, which could have an important effect on retirement adjustment. Retirement can be beneficial for people who are dissatisfied with their jobs because of stress and physical demands (Clark and Fawaz, 2009: 96; Wetzel, Huxhold and Tesch-Römer, 2016). Stronger identification with the workplace and job satisfaction are related to depression following retirement, especially in women, while men feel lower personal satisfaction (Kubicek et al., 2011: 243).

Aside from the loss of work, retirement also results in a lower income. A study by Van Solinge and Henkens (2008) indicates that lower income has a negative impact on retirement adjustment, whereas no effect was found in the study by Wang (2007). Studies conducted by Earl, Gerrans and Aryanto (2015), and Muratore and Earl (2015) demonstrated that people with low financial status are more likely to have problems in the process of retirement adjustment. Retirees who perceive their financial situation positively adapt more easily to changes following retirement and are also more satisfied with their new status (Wang and Shultz, 2010; Feldman and Beehr 2011; Nalin and Franca, 2015: 197). A good financial situation allows pensioners to take part in various activities, which can help alleviate post-retirement challenges (Van Solinge and Henkens, 2008: 428; Muratore and Earl, 2015: 2124). A study by Lovreković and Leutar (2010: 76) conducted in retirement homes also confirmed that the financial situation is undoubtedly one of the important preconditions for a peaceful old age.

\section{OBJECTIVE AND HYPOTHESES}

The objective of this study is to identify differences in retirement adjustment with regards to certain socioeconomic characteristics (level of education, type of occupation, retirement length, type of retirement, monthly income level) in the elderly living in retirement homes. The differences in adaptation to retirement according to socioeconomic characteristics will be examined according to Atchley's (2000) Model of Retirement Adjustment.

The following main hypothesis is derived from the previously presented theoretical concepts and studies: retirement adjustment in the elderly living in retirement homes varies with regard to their socioeconomic characteristics. This hypothesis was operationalised into five testable hypotheses: retirement adjustment in the elderly living in retirement homes varies with regard to the level of education $(\mathrm{H} 1)$, with regard to the type of occupation $(\mathrm{H} 2)$, with regard to retirement length (length 
of retirement status; $\mathrm{H} 3)$, with regard to the type of retirement $(\mathrm{H} 4)$ and with regard to monthly income (H5).

\section{METHODOLOGY}

\subsection{Sample and data collection}

The research was conducted in spring 2018 in retirement homes in the Croatian town of Bjelovar and the city of Zagreb. It included 214 elderly people of both genders aged 65 and over, who resided in retirement homes. The institutions included in the research were Dom za starije osobe Bjelovar (Bjelovar Retirement Home), Dom za starije i nemoćne osobe Vita Nova Bjelovar (Vita Nova Nursing Home Bjelovar) and Dom za starije i nemoćne osobe Kuća svetog Franje (St Francis' Nursing Home) in Zagreb. These institutions were chosen because they provide several levels of care for the elderly and have more than 100 beneficiaries, which ensured a wider range of participants. One is state-managed, (Bjelovar Retirement Home) while the other two are privately owned. This distinction was important as there may be a difference in the financial independence of the residents (cf. Lovreković and Leutar, 2010: 76) that could affect retirement adjustment.

The participants who met the research criteria were chosen among residents in retirement homes with the help of social workers. The research did not include the elderly with severe cognitive and psychophysical disorders such as dementia, mental illnesses or complete immobility. In order to participate in the study, senior citizens also had to confirm that they had a retirement status defined by not being employed and receiving a pension from the retirement fund. The study included the elderly on regular or temporary retirement, while those who were registered at the unemployment office until reaching the retirement age were excluded, since their path to retirement diverged from the propositions of the assessed model.

Face-to-face interviews were conducted individually by the authors of the research in participant's rooms. The interviewers read questions to participants and noted their answers. On average, the interviews took 23 minutes to complete. Prior to conducting the survey, permission was obtained from the retirement home's board and executive director. Participation was voluntary and confidential.

The questionnaire was completed by 214 participants, which makes $42.3 \%$ of the total number of beneficiaries in the chosen institutions. 154 (73.4\%) participants were from Bjelovar retirement homes and 57 (26.63\%) from the Zagreb retirement home. Three questionnaires $(1.41 \%)$ had to be excluded from the analyses due to the amount of missing data. It is important to note that none of the selected participants refused to take part in the survey. 


\subsection{Measures}

The first part of the questionnaire consisted of the following eight sociodemographic and socioeconomic items: gender, age, marital status (married, single, divorced or widowed), education (did not finish primary school, 8-year primary school, secondary education, bachelor's degree equivalent, master's degree equivalent, master of science or Ph.D.), length of retirement (0-8 years, 9-16 years, 17-24 years, 25 years and more), type of retirement (regular, early, disability, family, veteran), monthly income (HRK 500-2,000; HRK 2,001-3,500; HRK 3,501-5,000; HRK 5,001 or more) and pre-retirement occupation categorised according to the occupational classification (Croatian Bureau for Statistics, 2010; International Labour Organisation, 2012: 14).

The second part of the survey questionnaire consisted of the standardised Retirement Adjustment Factor Questionnaire designed by Penezić, Lacković-Grgin and Lukačić (2014: 71-77) with the purpose of assessing Atchley's (2000) Model of Retirement Adjustment Factor. The questionnaire consists of 67 items, 44 of which are divided into six subscales (Routine, Pre-Retirement, Honeymoon, Disenchantment, Termination, and Reactivation) and 23 items that the authors (Penezić, Lacković-Grgin and Lukačić, 2014) considered justified to include for a better understanding of the retirement process. The answers to all items were based on a five-point scale (from $1=$ does not relate to me at all, to $5=$ relates to me completely). Internal consistency of the subscales was acceptable (Table 1).

Table 1. Cronbach's a coefficients for six subscales of the Retirement Adjustment Factor Questionnaire

\begin{tabular}{lcc}
\hline subscales & number of items & Cronbach's $\alpha$ \\
\hline Pre-Retirement Phase & 7 & 0.74 \\
\hline Honeymoon Phase & 6 & 0.72 \\
\hline Disenchantment Phase & 3 & 0.72 \\
\hline Routine Phase & 14 & 0.84 \\
\hline Termination Phase & 8 & 0.74 \\
\hline Reactivation Phase & 6 & 0.71 \\
\hline
\end{tabular}




\subsection{Sociodemographic and socioeconomic characteristics of the participants}

Women constituted $62 \%$ of the sample $(\mathrm{N}=211)$. The youngest participant was 67 years old, and the oldest 92 . The average age was $81(\mathrm{SD}=5.12)$, which was also the most common age in the sample. Most participants were widowed (54.6\%), followed by those who were married or lived in a common-law marriage $(32.7 \%)$, divorced $(11.5 \%)$, while only $1.2 \%$ were single.

Most participants graduated from secondary school (38.6\%), followed by those who completed 8-year elementary school $(22.1 \%)$ and those with a B.A. $(19.4 \%)$ or an M.A. degree (16.8\%). The fewest number of participants did not attend or finish school $(1.9 \%)$ or had an MSc or a PhD (1.2\%). The average length of retirement was 20.1 years $(S D=6.48)$, the shortest being three years and the longest 41 years.

Most participants (32.7\%) had a monthly income of over HRK 5,001, while just $13 \%$ fell into the HRK 500-2,000 category. The grouped data average income was HRK 4,125.19. According to the Act of Pension Insurance (Croatian Pension Insurance Institute, 2018), the average pension in Croatia was HRK 2,286.66 at the time of the study, which means that the participants' average income was considerably higher than the average pension.

\subsection{Analytical strategy}

The Kolmogorov-Smirnov test and the Shapiro-Wilk test were used to determine data distribution normality. Since the obtained values of the majority of distributions deviated significantly from the normal distribution $(p<0.05)$, nonparametric methods were used to test the difference between the groups. The Kruskal-Wallis analysis of variance was used for more than two groups and to identify them, while the Mann-Whitney post hoc test was conducted to assess the differences between pairs of categories within the Retirement Adjustment Factor Questionnaire subscales and the total result. All testing procedures were conducted using the $p \leq 0.01$ threshold. The analyses were carried out using the IBM SPSS V23.0 statistical package. 


\section{RESULTS}

\subsection{Results of participants with different levels of education on the Retirement Adjustment Factor Questionnaire}

The results of different categories of participants with regard to the level of education diverged in the Pre-Retirement, Honeymoon, Routine and Termination Phase subscales of the Questionnaire (Table 2).

Table 2. Results of the Kruskal-Wallis comparison test between the results of participants with different levels of education on the Retirement Adjustment Factor Questionnaire

\begin{tabular}{lcc}
\hline phases & Chi-Square & $p$ \\
\hline Pre-Retirement & 20.42 & $<0.01$ \\
\hline Honeymoon & 25.82 & $<0.001$ \\
\hline Disenchantment & 8.58 & 0.31 \\
\hline Routine & 31.55 & $<0.01$ \\
\hline Termination & 30.65 & $<0.001$ \\
\hline Reactivation & 3.03 & 0.55 \\
\hline
\end{tabular}

Grouping Variable: level of education

A post hoc analysis was conducted using the Mann-Whitney test to assess the differences between pairs of categories within the abovementioned subscales. In Table 3, only the pairs of categories that were significantly different are presented. The Pre-Retirement subscale shows that participants with a bachelor's or master's degree achieved higher scores than participants who finished primary school. Participants with a higher level of education undertook activities which helped them adapt to retirement better than participants with lower education. The results for the Honeymoon and Routine subscales show that participants with a bachelor's or master's degree achieved higher results than participants with primary education, while the participants with a master's degree had higher results than those with secondary education. These results indicate that participants with higher education are more positive about retirement and that they embraced their role as retirees better than participants with lower education owing to their routines and a set of criteria. In contrast, participants with primary education obtained much higher results than participants with a master's and bachelor's degree on the Termination Phase 
subscale, while participants with secondary education obtained higher results than those with a master's degree. This means that participants with a lower level of education are less focussed on their role as pensioners because they are preoccupied with issues such as illness, frailty or loneliness.

Table 3. Results of the Mann-Whitney test of the differences among the results in the Pre-Retirement, Honeymoon, Routine and Termination Phase subscales in participants with regard to the level of education

\begin{tabular}{|c|c|c|c|c|}
\hline phases & level of education & $\mathrm{N}$ & mean rank & $p$ \\
\hline \multirow{4}{*}{$\begin{array}{l}\text { Pre- } \\
\text { Retirement }\end{array}$} & Primary school & 49 & 41.37 & \multirow{2}{*}{$<0.01$} \\
\hline & Bachelor's degree & 34 & 66.68 & \\
\hline & Primary school & 49 & 39.48 & \multirow{2}{*}{$<0.01$} \\
\hline & Master's degree & 39 & 66.26 & \\
\hline \multirow{6}{*}{ Honeymoon } & Primary school & 49 & 42.01 & \multirow{2}{*}{$<0.01$} \\
\hline & Bachelor's degree & 34 & 79.17 & \\
\hline & Primary school & 49 & 40.56 & \multirow{2}{*}{$<0.001$} \\
\hline & Master's degree & 39 & 79.54 & \\
\hline & Secondary school & 80 & 56.83 & \multirow{2}{*}{$<0.01$} \\
\hline & Master's degree & 39 & 91.25 & \\
\hline \multirow{6}{*}{ Routine } & Primary school & 49 & 37.63 & \multirow{2}{*}{$<0.01$} \\
\hline & Bachelor's degree & 34 & 89.38 & \\
\hline & Primary school & 49 & 37.37 & \multirow{2}{*}{$<0.01$} \\
\hline & Master's degree & 39 & 86.83 & \\
\hline & Secondary school & 80 & 59.98 & \multirow{2}{*}{$<0.01$} \\
\hline & Master's degree & 39 & 103.45 & \\
\hline \multirow{6}{*}{ Termination } & Primary school & 49 & 69.53 & \multirow{2}{*}{$<0.01$} \\
\hline & Bachelor's degree & 34 & 44.10 & \\
\hline & Primary school & 49 & 90.42 & \multirow{2}{*}{$<0.001$} \\
\hline & Master's degree & 39 & 42.05 & \\
\hline & Secondary school & 80 & 92.18 & \multirow{2}{*}{$<0.01$} \\
\hline & Master's degree & 39 & 65.66 & \\
\hline
\end{tabular}




\subsection{Results of participants with different occupations on the Retirement Adjustment Factor Questionnaire}

The results of different categories of participants with regard to the type of occupation diverged in the Honeymoon, Routine and Termination Phase subscales of the Retirement Adjustment Factor Questionnaire (Table 4).

Table 4. Results of the Kruskal-Wallis comparison test between the results of participants with different occupations on the Retirement Adjustment Factor Questionnaire

\begin{tabular}{lcc}
\hline phases & Chi-Square & $p$ \\
\hline Pre-Retirement & 15.37 & 0.04 \\
\hline Honeymoon & 26.42 & $<0.01$ \\
\hline Disenchantment & 8.24 & 0.51 \\
\hline Routine & 25.33 & $<0.01$ \\
\hline Termination & 28.24 & $<0.001$ \\
\hline Reactivation & 6.36 & 0.42 \\
\hline
\end{tabular}

Grouping Variable: type of occupation

The Mann-Whitney post hoc test analysis was conducted to test the differences between pairs of categories within those subscales. In Table 5, only the pairs of categories that were significantly different are presented. It is apparent from the Honeymoon and Routine Phase subscales that scientists, engineers and specialists obtained higher results than participants who worked in crafts and individual production or had simple occupations, or those in services and trade. It seems that participants who were scientists, engineers and specialists accepted their role as retirees owing to their satisfactory routines and a set of criteria. They were also more positive about retirement than participants who were engaged in services, trade, crafts, individual production and simple occupations. In contrast, participants who worked in services and trade or had simple occupations achieved higher results on the Termination Phase subscale than participants who were scientists, engineers and specialists. This suggests that those engaged in simple occupations, services and trade are less focussed on their role as pensioners and are more preoccupied with other issues, most often illness, frailty or loneliness. 
Table 5. Results of the Mann-Whitney test of the difference between the results for the Honeymoon, Routine and Termination Phase subscales in participants with regard to the type of occupation

\begin{tabular}{|c|c|c|c|c|}
\hline phases & type of occupation & $\mathrm{N}$ & mean rank & $\mathrm{p}$ \\
\hline \multirow{6}{*}{ Honeymoon } & Scientists, engineers and specialists & 62 & 86.65 & \multirow{2}{*}{$<0.01$} \\
\hline & Services and trade & 40 & 50.50 & \\
\hline & Scientists, engineers and specialists & 62 & 86.82 & \multirow{2}{*}{$<0.01$} \\
\hline & Craft and individual production & 45 & 53.10 & \\
\hline & Scientists, engineers and specialists & 62 & 81.31 & \multirow{2}{*}{$<0.001$} \\
\hline & Simple occupations & 30 & 40.22 & \\
\hline \multirow{6}{*}{ Routine } & Scientists, engineers and specialists & 62 & 85.47 & \multirow{2}{*}{$<0.01$} \\
\hline & Services and trade & 40 & 47.51 & \\
\hline & Scientists, engineers and specialists & 62 & 87.27 & \multirow{2}{*}{$<0.001$} \\
\hline & Craft and individual production & 45 & 51.53 & \\
\hline & Scientists, engineers and specialists & 62 & 81.61 & \multirow{2}{*}{$<0.01$} \\
\hline & Simple occupations & 30 & 37.26 & \\
\hline \multirow{4}{*}{ Termination } & Scientists, engineers and specialists & 62 & 46.54 & \multirow{2}{*}{$<0.01$} \\
\hline & Services and trade & 40 & 84.96 & \\
\hline & Scientists, engineers and specialists & 62 & 47.42 & \multirow{2}{*}{$<0.001$} \\
\hline & Simple occupations & 30 & 91.05 & \\
\hline
\end{tabular}




\subsection{Results of participants with different lengths of retirement on the Retirement Adjustment Factor Questionnaire}

The results of participants with regard to the length of retirement differed only in the Honeymoon Phase subscale of the Retirement Adjustment Factor Questionnaire (Table 6).

Table 6. Results of the Kruskal-Wallis comparison test between the results of participants with different lengths of retirement on the Retirement Adjustment Factor Questionnaire

\begin{tabular}{lcc}
\hline phases & Chi-Square & $p$ \\
\hline Pre-Retirement & 4.58 & 0.18 \\
\hline Honeymoon & 16.05 & $<0.01$ \\
\hline Disenchantment & 5.82 & 0.28 \\
\hline Routine & 13.34 & 0.02 \\
\hline Termination & 4.33 & 0.36 \\
\hline Reactivation & 3.12 & 0.44 \\
\hline
\end{tabular}

Grouping Variable: retirement length

The Mann-Whitney post hoc test analysis was conducted to test the difference between pairs of categories. In Table 7, only the pairs of categories that were significantly different are presented. Expectedly, participants who had retired within 8 years were considerably more positive about retirement than those who had been retired for 25 years or more.

Table 7. Results of the Mann-Whitney test of the difference between the results in the Honeymoon Phase subscale in participants with regard to the length of retirement; $0-8$ years and 25 years and more

\begin{tabular}{lllcc}
\hline phases & length of retirement & $\mathrm{N}$ & mean rank & $\mathrm{p}$ \\
\hline \multirow{2}{*}{ Honeymoon } & 0-8 years & 20 & 64.92 & \multirow{2}{*}{$<0.01$} \\
\cline { 2 - 4 } & 25 years and more & 51 & 41.26 & \\
\hline
\end{tabular}




\subsection{Results of participants with different types of retirement on the Retirement Adjustment Factor Questionnaire}

The results of participants with regard to the type of retirement differed among the Pre-Retirement, Honeymoon, Routine and Termination subscales of the Retirement Adjustment Factor Questionnaire (Table 8).

Table 8. Results of the Kruskal-Wallis comparison test between the results of participants with different types of retirement on the Retirement Adjustment Factor Questionnaire

\begin{tabular}{lcc}
\hline phases & Chi-Square & $p$ \\
\hline Pre-Retirement & 21.51 & $<0.001$ \\
\hline Honeymoon & 40.56 & $<0.001$ \\
\hline Disenchantment & 5.30 & 0.84 \\
\hline Routine & 39.19 & $<0.001$ \\
\hline Termination & 34.86 & $<0.001$ \\
\hline Reactivation & 5.97 & 0.25 \\
\hline
\end{tabular}

Grouping Variable: type of retirement

The Mann-Whitney post hoc test analysis was conducted to test the differences between pairs of categories. In Table 9, only the pairs of categories that were significantly different are presented. Participants who took regular retirement at a normal retirement age had higher results in the Pre-Retirement subscale than participants who took an early retirement because of poor health. These results indicate that participants in regular retirement engaged in activities which helped them adjust better to retirement than participants who retired early for health reasons. As for the Honeymoon and Routine subscales, participants on regular retirement had higher results - a more positive attitude towards retirement, having embraced their role as pensioners better - than participants in early retirement because of poor health or those on disability retirement. In contrast, participants who took an early retirement because of poor health and those on disability retirement had higher results on the Termination subscale - meaning that they are less focussed on their role as pensioners and more preoccupied with other issues (most often disease, frailty or loneliness) - than participants who took regular retirement at a normal retirement age. 
Table 9. Results of the Mann-Whitney test of the difference among the Pre-Retirement, Honeymoon, Routine, and Termination Phases subscales in participants with regard to different types of retirement

\begin{tabular}{|c|c|c|c|c|}
\hline phases & type of retirement & $\mathrm{N}$ & mean rank & $\mathrm{p}$ \\
\hline \multirow[t]{2}{*}{ Pre-Retirement } & $\begin{array}{l}\text { Regular retirement at } \\
\text { normal retirement age }\end{array}$ & 107 & 90.18 & \multirow{2}{*}{$<0.01$} \\
\hline & Health problems & 35 & 52.07 & \\
\hline \multirow{4}{*}{ Honeymoon } & $\begin{array}{l}\text { Regular retirement at } \\
\text { normal retirement age }\end{array}$ & 107 & 99.13 & \multirow[t]{2}{*}{$<0.01$} \\
\hline & Health problems & 35 & 33.20 & \\
\hline & $\begin{array}{l}\text { Regular retirement at } \\
\text { normal retirement age }\end{array}$ & 107 & 92.42 & \multirow{2}{*}{$<0.01$} \\
\hline & Disability retirement & 28 & 50.05 & \\
\hline \multirow{4}{*}{ Routine } & $\begin{array}{l}\text { Regular retirement at } \\
\text { normal retirement age }\end{array}$ & 107 & 89.24 & \multirow{2}{*}{$<0.001$} \\
\hline & Health problems & 35 & 40.65 & \\
\hline & $\begin{array}{l}\text { Regular retirement at } \\
\text { normal retirement age }\end{array}$ & 107 & 96.57 & \multirow[t]{2}{*}{$<0.01$} \\
\hline & Disability retirement & 28 & 38.48 & \\
\hline \multirow{4}{*}{ Termination } & $\begin{array}{l}\text { Regular retirement at } \\
\text { normal retirement age }\end{array}$ & 107 & 57.13 & \multirow[t]{2}{*}{$<0.01$} \\
\hline & Health problems & 35 & 96.26 & \\
\hline & $\begin{array}{l}\text { Regular retirement at } \\
\text { normal retirement age }\end{array}$ & 107 & 63.55 & \multirow{2}{*}{$<0.01$} \\
\hline & Disability retirement & 28 & 102.20 & \\
\hline
\end{tabular}




\subsection{Results of participants with different monthly incomes on the Retirement Adjustment Factor Questionnaire}

Finally, the results of participants with regard to income differed among the Pre-Retirement, Honeymoon, Routine and Termination Phase subscales of the Retirement Adjustment Factor Questionnaire (Table 10).

Table 10. Results of the Kruskal-Wallis comparison test between the results of participants with different monthly incomes on the Retirement Adjustment Factor Questionnaire

\begin{tabular}{lcc}
\hline phases & Chi-Square & $p$ \\
\hline Pre-Retirement & 35.21 & $<0.01$ \\
\hline Honeymoon & 52.46 & $<0.001$ \\
\hline Disenchantment & 5.31 & 0.25 \\
\hline Routine & 42.25 & $<0.001$ \\
\hline Termination & 45.45 & $<0.001$ \\
\hline Reactivation & 3.49 & 0.48
\end{tabular}

Grouping Variable: monthly income

A post hoc analysis in the form of the Mann-Whitney test was conducted to test the differences between pairs of categories. In Table 11, only the pairs of categories that were significantly different are presented. Participants with an income of over HRK 5,001 had higher results in the Pre-Retirement subscale (i.e. engaged more in activities which helped them adjust better to retirement) than participants with a lower income (HRK 500-3,500). Those with an income of over HRK 5,001 had higher results on the Honeymoon subscale than participants with a lower income (all categories), while participants with an income of HRK 3,501-5,000 had higher results than the participants with the HRK 500-2,000 income. These results mean that participants with a higher income have a more positive attitude towards retirement than those with a lower income. As for the Routine subscale, participants with an income of over HRK 5,001 had higher results than participants with a lower income (HRK 500-3,500), while participants with an income of HRK 3,501-5,000 achieved higher results than those with an income of HRK 500-2,000. This means that higher income is associated with higher acceptance of the role of retirees. In contrast, participants with an income of HRK 500-3,500 achieved higher results on the Termination scale (meaning that they were less focussed on their role as 
retirees and more preoccupied with disease, frailty or loneliness) than those with anincome of over HRK 3,501.

Table 11. Results of the Mann-Whitney test of the difference among the PreRetirement, Honeymoon, Routine, and Termination Phase subscales in participants with regard to their monthly income

\begin{tabular}{|c|c|c|c|c|}
\hline phases & $\begin{array}{l}\text { the amount of monthly } \\
\text { income }\end{array}$ & $\mathrm{N}$ & mean rank & $p$ \\
\hline \multirow{4}{*}{ Pre-Retirement } & HRK 500-2,000 & 30 & 28.13 & \multirow{2}{*}{$<0.01$} \\
\hline & over HRK 5,001 & 68 & 65.54 & \\
\hline & HRK 2,001-3,500 & 57 & 57.73 & \multirow{2}{*}{$<0.001$} \\
\hline & over HRK 5,001 & 68 & 82.45 & \\
\hline \multirow{8}{*}{ Honeymoon } & HRK 500-2,000 & 30 & 24.50 & \multirow{2}{*}{$<0.01$} \\
\hline & HRK 3,501-5,000 & 51 & 82.60 & \\
\hline & HRK 500-2,000 & 53 & 56.34 & \multirow{2}{*}{$<0.001$} \\
\hline & over HRK 5,001 & 68 & 92.50 & \\
\hline & HRK 2,001-3,500 & 57 & 52.87 & \multirow{2}{*}{$<0.01$} \\
\hline & over HRK 5,001 & 68 & 86.57 & \\
\hline & HRK 3,501-5,000 & 51 & 36.90 & \multirow{2}{*}{$<0.01$} \\
\hline & over HRK 5,001 & 68 & 72.70 & \\
\hline \multirow{6}{*}{ Routine } & HRK 500-2,000 & 30 & 39.63 & \multirow{2}{*}{$<0.01$} \\
\hline & HRK 3,501-5,000 & 51 & 57.19 & \\
\hline & HRK 500-2,000 & 30 & 24.83 & \multirow{2}{*}{$<0.01$} \\
\hline & over HRK 5,001 & 68 & 86.56 & \\
\hline & HRK 2,001-3,500 & 57 & 51.38 & \\
\hline & over HRK 5,001 & 68 & 89.91 & $<0.001$ \\
\hline \multirow{4}{*}{ Termination } & HRK 500-2,000 & 30 & 66.87 & \multirow{2}{*}{$<0.01$} \\
\hline & HRK 3,501-5,000 & 51 & 39.27 & \\
\hline & HRK 500-2,000 & 30 & 89.86 & \multirow{2}{*}{$<0.01$} \\
\hline & over HRK 5,001 & 68 & 55.88 & \\
\hline
\end{tabular}




\section{DISCUSSION}

The aim of this study was to assess how the elderly living in retirement homes adjust to retirement with regard to their socioeconomic characteristics. The sociodemographic differences in adaptation to retirement were considered according to Atchley's (2000) Model of Retirement Adjustment. The study was focussed on the timely identification of factors that could increase a low level of retirement adjustment in older people. As the hypothesised association between retirement adjustment and the retiree's socioeconomic characteristics has been confirmed, our analyses provided several noteworthy insights.

Participants with a bachelor's or a master's degree adjusted to retirement better, which corresponds with the finding of previous studies; educated people were also better informed about retirement adjustment and pensioners' rights (Clark and Fawaz, 2009: 96). Likewise, participants who were scientists, engineers and specialists are better adjusted to retirement than participants who worked in services, trade, crafts, individual manufacturing or had simple occupations, since such occupations provide a high level of social skills that allow retirees to follow important and satisfactory activities (Heybroek, 2011: 12).

Participants differed on the Honeymoon subscale with regard to the length of retirement, while no differences were found in other subscales of the Questionnaire. These results confirm the applied theoretical model of the retirement adjustment process. Recently retired people can enter the Honeymoon Phase or an initial euphoric reaction during which they try to do and engage in all the activities they did not have time for while employed (Atchley and Barusch, 2004: 258). However, pensioners' initial increased sense of well-being and their adaptation to the retiree status is short-lived. The enthusiasm of the initial adjustment stage wanes when pensioners become more realistic about retirement, but stabilises later when they adapt to the new life.

With regard to the length of retirement, there is evidence that retirement can initially be stressful, disquieting, but also pleasant. In any case, over time, most pensioners adapt well to their new status (Butterworth et al., 2006: 1188; Von Hippel, Henry and Matovic, 2008: 438). For this reason, the Atchley Model suggests that retirement adjustment has a non-linear trajectory because people can find themselves in very different adjustment phases at any given time due to individual differences in experiencing retirement (Taylor et al., 2008: 467; Gobeski and Beehr, 2009: 417; Penezić, Lacković-Grgin and Lukačić, 2014: 67). To avoid the influence of factors such as the time spent in retirement on the results obtained in our research, the questionnaire was designed to follow the framework of the time of appearance. For example, the Pre-Retirement phase dealt with the activities 
that participants undertook to be better prepared (whether they read books about retirement or asked about the rights of retirees).

The participants who took regular retirement at a normal retirement age reported that they adapted to retirement better than the participants who took an early retirement for health reasons or those on disability retirement. These results indicate that the type of retirement has an important role in retirement adjustment. A person's decision to retire voluntarily or at a normal age is positively related to the person's sense of well-being (De Vaus et al. 2007: 676; Hershey and Henkens, 2014: 233). However, taking early retirement due to ill health may have a negative impact on the person's sense of well-being (Calvo, Haverstick and Sass, 2009: 130; Hershey and Henkens 2014: 233; Dingemans and Henkens, 2015: 22). Studies show that early retirement can also have a negative effect on adjustment. People who unexpectedly take early retirement are more prone to depression, anxiety and stress compared to those who retire voluntarily (Van Solinge and Henkens, 2008: 430; Hershey and Henkens, 2014: 233).

Finally, the participants with a higher income adjusted better to retirement than those with a lower income - as demonstrated by a number of previous studies (Van Solinge and Henkens, 2008: 429; Earl, Gerrans and Aryanto, 2015: 366; Muratore and Earl, 2015: 2124). In addition, pensioners who perceive their financial situation positively find it easier to adapt to the changes retirement brings and are more satisfied with their new status (Wang and Shultz, 2010; Feldman and Beehr, 2011; Nalin and Franca, 2015: 197). Sound finances enable pensioners to participate in more activities (the Honeymoon subscale) that can alleviate the challenges brought about by retirement (Van Solinge and Henkens, 2008: 428; Muratore and Earl, 2015: 2124).

\section{CONCLUSION}

This study aspires to encourage reflection on how the elderly experience the retirement adjustment process. This process is influenced by numerous factors which can affect each individual in a different way. It requires planning and adaptation, which can take several years. A person can go through a series of phases during the period of adjustment. It is important to note that retirement is a long-lasting period in life which must not be ignored as it is of the utmost importance not just for the elderly, but also for their families and society as a whole.

Using the standardised Retirement Adjustment Factor Questionnaire, we detected some of the many factors that influence adaptation to retirement and ageing. The results obtained in this study confirmed that socioeconomic characteristics such as level of education, type of retirement, level of monthly income and type 
of occupation affect the success of retirement adjustment (Van Solinge and Henkens, 2007; Hershey and Henkens, 2014; Heybroek, Haynes and Baxter, 2015). A better socioeconomic status enables people to have more opportunities in society, increases their sense of security and provides greater life satisfaction - all of which will ultimately be reflected in the quality of their lives and retirement adjustment. It was also indicated that type of retirement (forced or voluntary) and social norms that determine the expected retirement age have an important role in retirement adjustment.

Our findings have possible implications for the design of social programmes to improve the quality of life of the elderly and provide a better understanding of how older people living in retirement homes experience retirement. They emphasise the need for opening counselling centres specialised in providing advisory assistance to people who are preparing for retirement and/or for those that are already retired but are having difficulty adjusting to retirement. Furthermore, the findings can contribute to academic and public debates. The socioeconomic issues relating to retirement are of great public interest due to the negative demographic trends and ageing population, which affects future reforms and sustainability of retirement funds.

Lastly, it is necessary to address the main study limitations and provide recommendations for future research. Conducting the research on a fairly small and geographically limited sample resulted in limiting the range of possible analyses, the power of the applied tests and generalisability of the findings. In addition, the study did not include a group of pensioners who do not live in retirement homes, whose adaptation to retirement and its correlates may be different. The findings should therefore be regarded as the starting point for further studies that will provide a deeper understanding of the topic. This may also be achieved by combing quantitative with qualitative research methods, as well as by accounting for associations between retirement adjustment and other health-related and social factors such as social support from family and friends and participation in activities organised by the community.

\section{REFERENCES}

Akrap A, Barić V, Gelo J, Čipin I, Smolić Š and Strmota M (2013). Ekonomika starenja u Hrvatskoj [Economics of Ageing in Croatia]. Zagreb: Ekonomski fakultet.

Atchley RC (1976). The sociology of retirement. New York: Wiley.

Atchley RC (2000). Social Forces and Aging: An Introduction to Social Gerontology, 9th Edition. Belmont: Wadsworth. 
Atchley RC and Barusch AS (2004). Social Forces and Aging: An Introduction to Social Gerontology, 10th Edition. Belmont: Wadsworth.

Blieszner R (2000). Close relationship in old age. In: Hendricks C and Hendricks SS (eds.). Close relationships: A source book. London: Sage, 83-94. https://doi. org/10.4135/9781452220437.n7

Brajković L (2010). Pokazatelji zadovoljstva životom u trećoj životnoj dobi [Indicators of life satisfaction among the elderly]. Zagreb: Medicinski fakultet.

Brajković L (2011). Kvaliteta života u trećoj životnoj dobi nakon umirovljenja [Quality of life after retirement among the elderly]. In: Vuletić G (ed.). Kvaliteta života i zdravlje [Quality of life and health]. Osijek: Filozofski fakultet, 93-118.

Butterworth P, Gill S, Rodgers B, Anstey K, Villamil E and Melzer D (2006). Retirement and mental health: Analysis of the Australian national survey of mental health and well-being, Social Science and Medicine, 62 (5): 1179-1191. https://doi.org/10.1016/j. socscimed.2005.07.013

CalvoE, HaverstickKand Sass S(2009). Gradual retirement, ofcontrol, and retirees'happiness, Research on Aging, 31 (1): 112-135. https://doi.org/10.1177/0164027508324704

Calvo E, Sarkisian N and Tamborini C (2013). Causal effects of retirement timing on subjective physical and emotional health, The Journals of Gerontology: Series B, 68 (1): 73-84. https://doi.org/10.1093/geronb/gbs097

Clark A and Fawaz Y (2009). Valuing Jobs via Retirement: European Evidence, National Institute Economic Review, 209 (1): 88-103. https://doi.org/10.1177/0027950109345236

Crandall RC (1991). Gerontology: A Behavioral Science Approach. New York: McGraw-Hill.

Croatian Bureau of Statistics (2010). National Classification of Occupations 2010 - NKZ 10. Zagreb, Croatian Bureau of Statistics.

Croatian Bureau of Statistics (2013). Census of Population, Households and Dwellings 2011. Zagreb: Croatian Bureau of Statistics.

Croatian Pension Insurance Institute (2018). Statistical information of the Croatian Pension Insurance Institute. Zagreb: Croatian Pension Insurance Institute.

De Vaus D, Wells Y, Kendig H and Quine S (2007). Does Gradual Retirement Have Better Outcomes Than Abrupt Retirement? Results from an Australian Panel Study, Ageing and Society, 27 (5): 667-682. https://doi.org/10.1017/S0144686X07006228

Denton F and Spencer B (2009). What is retirement? A review and assessment of alternative concepts and measures, Canadian Journal on Aging, 28 (1): 63-76. https:// doi.org/10.1017/S0714980809090047

Dingemans E and Henkens K (2015). How do retirement dynamics influence mental wellbeing in later life? A 10-year panel study, Scandinavian Journal of Work Environment and Health, 41 (1): 16-23. https://doi.org/10.5271/sjweh.3464

Earl J, Gerrans P and Aryanto HV (2015). Active and adjusted: Investigating the contribution of leisure, health and psychosocial factors to retirement adjustment, Leisure Sciences, 37 (4): 354-372. https://doi.org/10.1080/01490400.2015.1021881

Ehler A, Naegele G and Reichert M (2011). Volunteering by older people in the EU. Luxembourg: Publications Office of the European Union.

Elovainio M, Forma P, Kivimäki M, Sinervo T, Sutinen R and Laine M (2005). Job demands and job control as correlates of early retirement thoughts in Finnish social and health care employees, Work Stress, 19 (1): 84-92. https://doi.org/10.1080/02678370500084623 
Eurostat (2016). Population_statistics_at_regional_level. Luxembourg: Eurostat.

Feldman D and Beehr T (2011). A three-phase model of retirement decision making, American Psychologist, 66 (3): 193-203. https://doi.org/10.1037/a0022153

Gobeski K and Beehr T (2009). How retirees work: Predictors of different types of bridge employment, Journal of Organizational Behavior, 30 (3): 401-425. https://doi. org/10.1002/job.547

Heybroek L (2011). Life Satisfaction and Retirement: A Latent Growth Mixture Modelling Approach. Brisbane: University of Queensland.

Heybroek L, Haynes M and Baxter J (2015). Life Satisfaction and Retirement in Australia: A Longitudinal Approach, Work, Aging and Retirement, 1 (2): 166-180. https://doi. org/10.1093/workar/wav006

Hershey DA and Henkens K (2014). Impact of Different Types of Retirement Transitions on Perceived Satisfaction with Life, The Gerontologist, 54 (2): 232-244. https://doi. org/10.1093/geront/gnt006

International Labour Organization (2012). International standard Classification of occupations - ISCO 08 (Volume 1). Geneve: International Labour Organization.

Kubicek B, Korunka C, Raymo JM and Hoonakker P (2011). Psychological well-being in retirement: The effects of personal and gendered contextual resources, Journal of Occupational Health Psychology, 16 (2): 230-246. https://doi.org/10.1037/a0022334

Latif E (2011). The impact of retirement on psychological well-being in Canada, The Journal of Socio-Economics, 40 (4): 373-380. https://doi.org/10.1016/j.socec.2010.12.011

Lovreković M and Leutar Z (2010). Kvaliteta života osoba u domovima za starije i nemoćne osobe u zagrebu [Quality of Life of People in Homes for the Elderly and Disabled in Zagreb], Socijalna ekologija, 19 (1): 55-79.

Muratore AM and Earl JK (2015). Improving retirement outcomes: The role of resources, pre-retirement planning and transition characteristics, Ageing and Society, 35 (10): 2100-2140. https://doi.org/10.1017/S0144686X14000841

Nalin CP and França, LHFP (2015). The Importance of Resilience for Well-Being in Retirement, Paidéia (Ribeirão Preto), 25 (61): 191-199. https://doi.org/10.1590/198243272561201507

Ovesnik R, Ovsenik M, Kmetec P and Valenčak U (2012). Priprema na umirovljenje i kvaliteta slobodnog vremena seniora [Preparations for retirement and the quality of leisure among senior citizens]. In: Plenković M (ed.). Society And Technology 2012 - Dr. Juraj Plenković. Zagreb: Hrvatsko komunikološko društvo, 565-659.

Palmore EB, Fillenbaum GG and George LK (1984). Consequences of retirement, Journal of Gerontology, 39 (1): 109-116. https://doi.org/10.1093/geronj/39.1.109

Penezić Z, Lacković-Grgin K and Bačinić A (2006). Proces umirovljenja: pokušaj provjere Atchleyeva modela prilagodbe [Process of retirement: An attempt at checking Atchley's model of adjustment], Medica Jadertina, 36 (3-4): 63-71.

Penezić Z, Lacković-Grgin K and Lukačić A (2014). Upitnik faktora prilagodbe na umirovljenje - MIR [The MIR Factors of Retirement Adjustment Questionnaire]. In: Ćubela Andorić V, Penezić Z, Proroković A and Tucak Junaković I (eds.). Zbirka psihologijskih skala i upitnika, svezak 7. Zadar: Sveučilište u Zadru, 65-77.

Pinquart $M$ and Schindler I (2007). Changes of life satisfaction in the transition to retirement: A latent-class approach, Psychology and Aging, 22 (3): 442-455. https://doi. org/10.1037/0882-7974.22.3.442 
Rhee M-K, Mor Barak M and Gallo W (2016). Mechanisms of the effect of involuntary retirement on older adults' self-rated health and mental health, Journal of Gerontological Social Work, 59 (1): 35-55. https://doi.org/10.1080/01634372.2015.1128504

Shultz KS and Wang M (2011). Psychological perspectives on the changing nature of retirement, American Psychologist, 66 (3): 170-179. https://doi.org/10.1037/a0022411

Taylor MA, Goldberg C, Shore L and Lipka P (2008). The effects of retirement expectations and social support on post-retirement adjustment: A longitudinal analysis, Journal of Managerial Psychology, 23 (4): 458-470. https://doi.org/10.1108/02683940810869051

Touhy T and Jett K (2014). Ebersole and Hess' Gerontological Nursing and Healthy Aging, 4th edition. St. Louis: Elsevier.

Van Solinge H and Henkens K (2007). Involuntary Retirement: The Role of Restrictive Circumstances, Timing, and Social Embeddedness, The Journals of Gerontology: Series B, 62 (5): 295-303. https://doi.org/10.1093/geronb/62.5.S295

Van Solinge H and Henkens K (2008). Adjustment to and Satisfaction With Retirement: Two of a Kind?, Psychology and Aging, 23 (2): 422-434. https://doi.org/10.1037/08827974.23.2.422

Von Hippel W, Henry JD and Matovic D (2008). Aging and social satisfaction: Offsetting positive and negative effects, Psychology and Aging, 23 (2): 435-439. https://doi. org/10.1037/0882-7974.23.2.435

Wang M (2007). Profiling retirees in the retirement transition and adjustment process: examining the longitudinal change patterns of retirees' psychological well-being, Journal of Applied Psychology, 92 (2): 455-474. https://doi.org/10.1037/0021-9010.92.2.455

Wang M and Shultz K (2010). Employee retirement: A review and recommendations for future investigation, Journal of Management, 36 (1): 172-206. https://doi. org/10.1177/0149206309347957

Warner SK and Willis SL (2001). Psihologija odrasle dobi i starenja [Psychology of adulthood and ageing]. Jastrebarsko: Naklada slap.

Wetzel M, Huxhold O and Tesch-Römer C (2016). Transition into retirement affects life satisfaction: Short- and long-term development depends on last labor market status and education, Social Indicators Research, 125 (3): 991-1009. https://doi.org/10.1007/ s11205-015-0862-4 


\title{
Socioekonomske razlike u prilagodbi na umirovljenje među starijim osobama koje žive u domovima umirovljenika
}

\author{
Želimir BERTIĆ \\ Alma Mater Europaea, Maribor, Slovenija \\ bertic.z@gmail.com \\ Mirjana TELEBUH \\ Zdravstveno veleučilište Zagreb, Zagreb, Hrvatska \\ mirjana.telebuh@zvu.hr \\ Mladen HAVELKA \\ Alma Mater Europaea, Maribor, Slovenija \\ mladen.havelka@gmail.com
}

\section{SAŽETAK}

Fenomeni starenja populacije u Hrvatskoj te povećanja broja starijih osoba koje dugo zadržavaju status umirovljenika zahtijevaju provođenje više istraživanja prilagodbe na umirovljenje. Ovo je istraživanje usmjereno na ostvarivanje jasnijeg uvida u odnos socioekonomskih karakteristika i prilagodbe na umirovljenje te prepoznavanja faktora kojima bi se moglo djelovati na smanjenje niske razine prilagodbe na umirovljenje kod starijih osoba. Istraživanje je provedeno metodom ankete u proljeće 2018. godine u domovima umirovljenika u Bjelovaru i Zagrebu, a obuhvatilo je 211 starijih osoba obaju spolova u dobi od 65 i više godina. Korišten je Upitnik faktora prilagodbe na umirovljenje za potrebe provjere Atchleyjeva modela prilagodbe na umirovljenje. Rezultati potvrđuju konceptualne pretpostavke prijašnjih analiza. Socioekonomske karakteristika kao što su razina obrazovanja, vrsta umirovljenja, razina mjesečnog primanja i vrsta zanimanja povezane su $s$ uspješnošću prilagodbe na umirovljenje u fazama pripreme, medenog mjeseca, stabilnosti i terminalne faze Atchleyjeva modela, dok je s fazom medenog mjeseca povezano samo trajanje umirovljenja. Osim poticanja akademskih i javnih rasprava, nalazi ovog istraživanja imaju potencijalnu implikaciju na socijalne programe osmišljene radi poboljšanja opće kvalitete života starijih osoba i pružanja boljeg razumijevanja kako odlazak u mirovinu doživljavaju institucionalizirane skupine starijih osoba.

Ključne riječi: prilagodba na umirovljenje, Atchleyjev model prilagodbe na umirovljenje, starije osobe, domovi umirovljenika, socioekonomske razlike 
